\title{
Towards better use of Indonesian peatlands with paludiculture and low-drainage food crops
}

\author{
Saritha Kittie Uda (1D - Lars Hein · Alma Adventa
}

Received: 30 August 2019/Accepted: 27 April 2020/Published online: 25 May 2020

(C) The Author(s) 2020

\begin{abstract}
The current drainage-based peatland management systems in Indonesia result in high fire risks, soil subsidence and $\mathrm{CO}_{2}$ emissions. This study aims to assess different alternatives of peatland crops in order to help prevent further degradation of peatlands in Indonesia. We focus on tropical peatland crops that provide food and that are of particular interest to smallholders. We compare various peatland food crops that are commonly grown with no drainage (paludiculture) or drainage below $50 \mathrm{~cm}$ in our study
\end{abstract}

Electronic supplementary material The online version of this article (https://doi.org/10.1007/s11273-020-09728-x) contains supplementary material, which is available to authorized users.

\section{S. K. Uda $(\bowtie) \cdot$ L. Hein}

Environmental Systems Analysis Group, Wageningen

University \& Research, P.O. Box 47,

6700 AA Wageningen, The Netherlands

e-mail: saritha.uda@wur.nl; sarithauda@fkip.upr.ac.id

L. Hein

e-mail: lars.hein@wur.nl

S. K. Uda

Biology Study Program, University of Palangka Raya, Jl Yos Sudarso, Palangka Raya 73111, Central Kalimantan, Indonesia

A. Adventa

Faculty of Engineering, University of Palangka Raya, J1

Yos Sudarso, Palangka Raya 73111, Central Kalimantan,

Indonesia

e-mail: alma.oceandy@gmail.com area, Central Kalimantan, Indonesia in terms of sustainability, profitability, scalability of the market and acceptability to farmers. Our results show that sago (Metroxylon sagu), banana (Musa paradisiaca) and pineapple (Ananas comosus) followed by water spinach/kangkong (Ipomoea aquatica), kelakai/edible fern (Stenochlaena palustris), illipe nut/tengkawang (Shorea spp.), dragon fruit (Hylocereus undatus), mangosteen (Garcinia mangostana) and sweet melon/ melon (Cucumis melo) are the best options based on the aggregated scores for these criteria (but precaution should be taken when planting crops that require low drainage). Sago palm and illipe nut have the highest scores for both sustainability and scalability of market, whereas banana, pineapple and sweet melon have the highest scores in term of the scalability of market and acceptability to farmers. We also address key opportunities and bottlenecks for the development of paludiculture food crops and present recommendations for the implementation of paludiculture in Indonesian peatlands.

Keywords Paludiculture - Crops · Peatland · Markets $\cdot$ Kalimantan $\cdot$ Indonesia 


\section{Introduction}

All peatlands in Indonesia were once forested, sequestering and storing atmospheric carbon for thousands of years (Warren et al. 2017; Page et al. 2011). Traditionally, indigenous people use peatlands for small-scale activities, such as harvesting nontimber forest products/species (Osaki et al. 2016; Limin and Jentha 2007). Starting from the 1980s, very large areas of Indonesian peatland have been drained and cultivated for plantation and smallholder cropping. Other areas have been opened for timber logging and land claiming but were then abandoned, which has led to extensive areas of degraded peatlands (Law et al. 2015). Oil palm, acacia and rubber plantations (industrial and smallholder plantations) have increasingly expanded to the peatland area (Gunarso et al. 2013; Miettinen et al. 2016; Schoneveld et al. 2019). Between 2000 and 2014, palm oil production from peatlands alone has increased by almost threefold (Uda et al. 2017). However, despite their economic benefits (in particular production for agricultural and forestry plantations), the conversion of natural peatlands has resulted in negative impacts on the environment and society. The conversion of natural tropical peatlands into other land uses leads to peat fires and the associated health effects, soil subsidence increasing flood risks, substantial greenhouse gas emissions and loss of biodiversity (Jafaar and Loh 2014; Marlier et al. 2015; Page and Hooijer 2016; Huijnen et al. 2016; Harrison and Rieley 2018).

In Indonesia, the drainage of natural peatlands was carried out through both legal (including activities by companies and government programs) and illegal canal constructions (e.g. for illegal logging or land grabbing). These activities were conducted at various scales, from local smallholder activities to large government programs such as the Mega Rice Project in Central Kalimantan. Currently, the Indonesian government has put a ban on the conversion of deep peat (over $3 \mathrm{~m}$ deep), however its enforcement in some areas is still lacking, and the boundary between deep and shallow peat is often unclear. Since domes are hydrological units and activities in one part of the dome will affect the whole dome, which can be up to several $10 \mathrm{~s}$ of $\mathrm{km}$ in diameter, concerted efforts are needed to restore and wisely manage Indonesian peatlands. Given that several million of hectares of land need to be rehabilitated, a productive and profitable use of peatlands that requires no or minimum drainage and also allows the sharing of benefits from peatland use among the people of Indonesia needs to be investigated (Dohong et al. 2018; Sinclair et al. 2019). Such efforts should consider both plantation and smallholder agriculture.

A sustainable alternative for utilizing peatland without drainage is paludiculture, which basically involves growing crops in peatland under conditions of no-drainage. A more elaborate definition was provided in Joosten et al. (2012) who defined paludiculture as "using biomass from wet and rewetted peatlands under conditions which maintain the peat body, facilitate peat accumulation and provide the ecosystem services associated to natural peatlands". Maintaining a high water table in paludiculture strongly reduces soil subsidence, fire risk and $\mathrm{CO}_{2}$ emissions (Giesen and Nirmala 2018; Joosten et al. 2016). For Indonesian climate, several paludiculture crops have been recommended for use in forestry, agroforestry, agro-food and as raw material for energy, construction and biochemical products (Tata and Susmianto 2016; Giesen 2013). Yet, it is important to understand the characteristics of each paludiculture crop before considering its widespread implementation. There are major differences between the paludiculture crops thus it is important to understand these when crops are tested or scaled-up locally.

We assess various paludiculture and non-paludiculture crops that can be grown with relatively high water tables in Indonesian peatlands, with a focus on their applicability in Central Kalimantan. We focus on tropical peatland crops that support food provision and food security while recognising that there are also promising non-food paludiculture crops providing resin, timber or other commodities (e.g. jelutung (Dyera sp.), ramin (Gonystylus bancanus), meranti and balangeran (Shorea sp), gemor (Nothaphoebe sp.), gelam/cajuput oil (Melaleuca cajuputi), etc.) (Giesen 2013; Noor et al. 2014; Graham et al. 2016; MoEFRI 2017; Giesen and Nirmala 2018). For this study, we included paludiculture crops as well as crops that require drainage at a level less than $50 \mathrm{~cm}$. The current oil palm best management practices were tested in peatlands that involve maintaining the water table at 40-60 cm (Lim et al. 2012), which was around half of the drainage level commonly found in oil palm plantations. Hence, some of the crops we examine here are in line with these low-drainage practices for 
oil palm (but these crops score relatively low on the sustainability criteria that we use). We proposed several criteria to assess the crops' sustainability, profitability, scalability of markets and acceptability to local farmers. We selected and compared 15 paludiculture food crops. A number of opportunities and bottlenecks on the implementation of these crops are addressed in this paper. We then provide recommendations for the successful implementation of food paludiculture crops and sustainable peatland management policy in Indonesia.

\section{Methods}

Study area for data collection

This study focused on peatlands in Central Kalimantan province which contains one of the largest peatland areas in Indonesia (2.6 million hectares, Ritung et al. 2011) and where we have access to local data through various ongoing and completed projects (e.g. Uda et al. 2017, 2018). Approximately $47 \%$ of the total peatland area in Central Kalimantan (1.2 million ha) is still forested (including degraded and well-preserved forests) and the remainder is either converted to plantation (mostly oil palm) or degraded (Surahman et al. 2018). Degraded peatlands are not used structurally for agriculture (some annual cropping with shifting cultivation may occur), mostly covered with ferns and shrubs, and burned frequently (typically at least once in 3 to 4 years). Since 2016 Central Kalimantan has been designated as one of the seven priority provinces for peatland restoration by the Peatland Restoration Agency (Badan Restorasi Gambut or $B R G$ ) set up by the Indonesian government to coordinate the restoration of 2.4 million hectares of degraded peatlands in Indonesia within five years (2016-2020). Based on the BRG's maps of peatland restoration priority areas, around 774,773 hectares of peatland areas in Central Kalimantan (distributed in 11 regencies of 14 regencies in Central Kalimantan) are part of the BRG's peatland restoration target (see Fig. 1, BRG 2018). The data collection was undertaken in ten villages located in peatland areas in five regencies distributed across the province. These villages were selected randomly in each regency and include Kapuas Regency (Basarang, Terusan Raya and Dadahup/Ex-Mega Rice Project villages), Pulang
Pisau Regency (Buntoi, Gohong and Jabiren villages), Katingan Regency (Kasongan Lama village), Gunung Mas Regency (Tampang Tumbang Anjir village), Palangka Raya city (Kalampangan and Menteng villages).

Interviews and selection of paludiculture crops

We selected 15 crops for our survey based on literature survey and discussions with local experts including the head of the local farmer groups, researchers from University of Palangka Raya, the Indonesian Peatland Restoration Agency and the Food Crop and Horticultural Agency of Central Kalimantan Province. From fifteen selected food crops, four are paludiculture crops (no drainage required) and eleven are crops where drainage between 0.2 and $0.5 \mathrm{~m}$ is required. We consulted the farmer groups in order to gather information on cultivation and marketing aspects of the crops. The data collection was undertaken during September-December 2017. In each village, a group of 10 to 15 farmers discussed the questions in the questionnaire and collectively filled in the response. The village discussions were moderated by the head of the local farmers association. The questionnaire is shown in Online Appendix 1 Supplementary Material. All groups were also contacted online following their response to clarify and discuss their answers. Furthermore, six in-depth interviews were held with the researchers from the University of Palangka Raya (3 researchers), staff in the Food Crop and Horticultural Agency of Central Kalimantan Province (1 staff) and the Indonesian Peatland Restoration Agency (2 staff). These were open interviews to discuss profitability, sustainability and scalability of various food crops assessed in this study.

\section{Performance criteria}

We assessed the crops using four criteria with one or more indicators for each criterion. The four criteria were sustainability, economic performance (Net Present Value), scalability (access to markets) and acceptability to farmers. Each crop was scored (values from 0 to 3 ) on each of these criteria. Subsequently, we aggregated these scores to obtain the total score for each crop, with an equal weighing for each criterion. Regarding sustainability, we considered that the drainage of peat and $\mathrm{CO}_{2}$ emissions as the most 


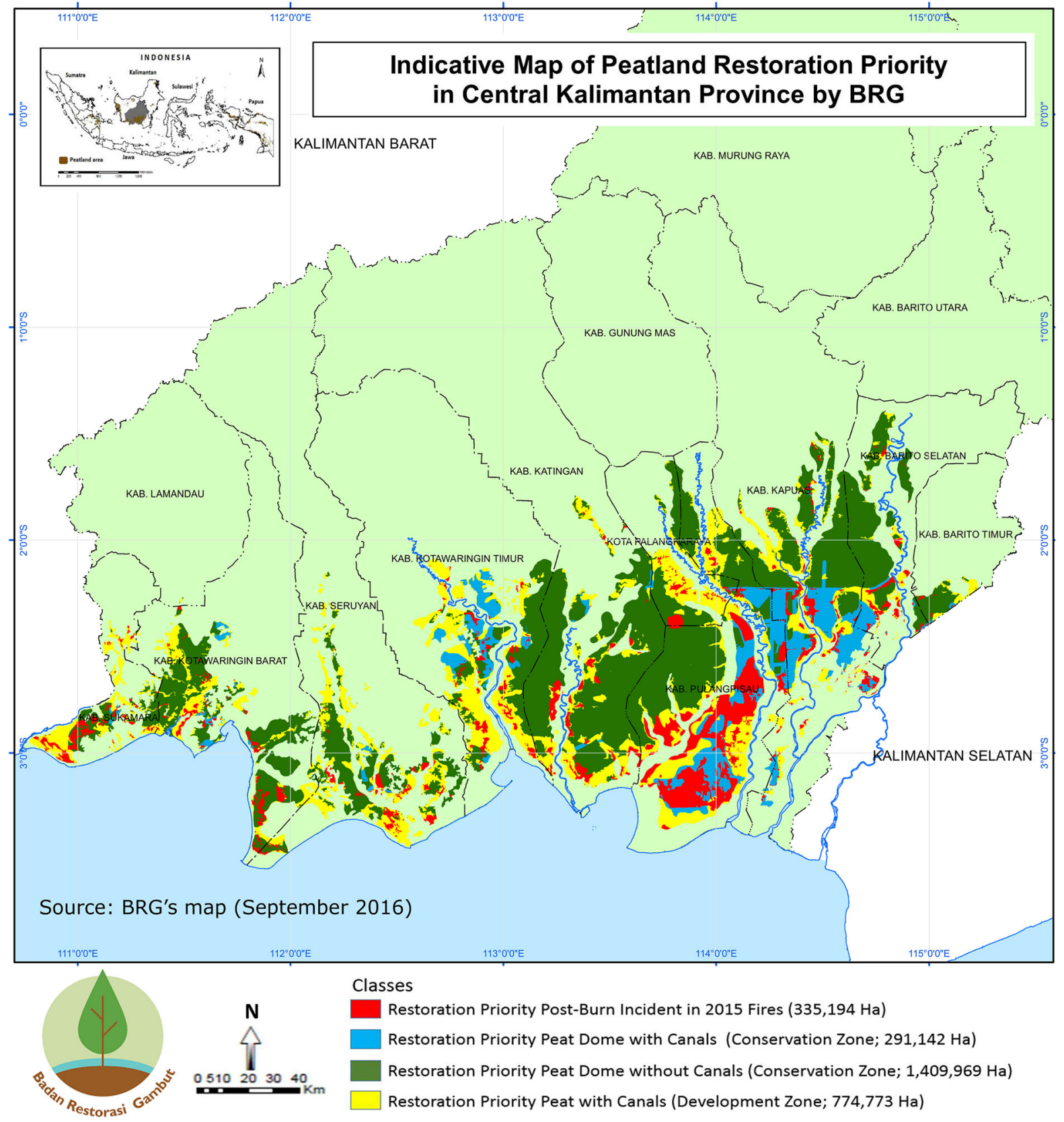

Fig. 1 Peatland distribution and indicative restoration priority map in Central Kalimantan (adapted from BRG 2018). Insert: Indonesian peatland distribution map (Ritung et al. 2011), Central Kalimantan province is indicated in grey

important ecological factors since they were closely related to the fire risk, haze, local health impacts as well as global warming. Acceptability to the local farmers was assessed on the basis of the ease of growing the crop (e.g. access to seedlings), maintenance and the amount of years the farmers had to wait to obtain their first harvest. The indicators and assessment methods are described in Table 1. Data were obtained from the questionnaires and interviews with the farmers/peatland users, experts and other relevant stakeholders and also from various case studies and government reports (e.g. BPS 2018a, b; 
Table 1 Indicators and methods for integrated assessment of socio-ecological aspects of the crops

\begin{tabular}{|c|c|c|c|}
\hline Indicator & Method & Description & Sources \\
\hline \multirow[t]{2}{*}{$\begin{array}{l}\text { (1) Sustainability tree crops group (the } \\
\text { emission factor is related to drained } \\
\text { natural forest on peat) non-tree crops } \\
\text { group (the emission factor is related to } \\
\text { deforested unproductive peatlands) }\end{array}$} & $\begin{array}{l}\mathrm{CO}_{2} \text { emission } \\
\left(\mathrm{t} \mathrm{CO}_{2}\right. \\
\left.\mathrm{ha}^{-1} \mathrm{year}^{-1}\right)\end{array}$ & $\begin{array}{l}\text { CO2emission }=-98 \times \text { WTDx } \\
\text { WTD is the water table depth below the } \\
\text { peat surface in meter (negative) of the } \\
\text { crop, } X \text { is the crop, } 98 \text { is the } \mathrm{CO}_{2} \\
\text { emissions factor used for tree crops ( } \mathrm{t} \\
\mathrm{CO}_{2} \text { ha }^{-1} \text { year }\end{array}$ & $\begin{array}{l}\text { Hooijer et al. (2012); } \\
\text { data from literature, } \\
\text { questionnaires and } \\
\text { interviews }\end{array}$ \\
\hline & $\begin{array}{l}\mathrm{CO}_{2} \text { emission } \\
\left(\mathrm{t} \mathrm{CO}_{2}\right. \\
\left.\mathrm{ha}^{-1} \text { year }^{-1}\right)\end{array}$ & $\begin{array}{l}C O 2 \text { emission }=9-84 \times W T D x \\
W T D \text { is the water table depth below the } \\
\text { peat surface in meter (negative) of the } \\
\text { crop, } 9 \text { and } 84 \text { are the factors for } \mathrm{CO}_{2} \\
\text { emissions for deforested unproductive } \\
\text { peatlands }\left(\mathrm{t} \mathrm{CO}_{2} \mathrm{ha}^{-1} \text { year }^{-1} \mathrm{~m}^{-1}\right)\end{array}$ & $\begin{array}{l}\text { Hooijer et al. (2012); } \\
\text { data from literature, } \\
\text { questionnaires and } \\
\text { interviews }\end{array}$ \\
\hline (2) Profitability & $\begin{array}{l}\text { Net present } \\
\text { value } \\
\text { (NPV), in } \\
\text { euro }\end{array}$ & $\begin{array}{l}N P V=\sum_{t=0}^{n}(B t-C t) \times \frac{1}{(1+r)^{t}} \\
N P V \text { is the Net Present Value of the crop, } \\
B \text { is the annual revenue of the crop, } C \text { is } \\
\text { the annual costs of growing the crop, } r \text { is } \\
\text { the discount rate, } t \text { is the year, } n \text { is the } \\
\text { time period considered }\end{array}$ & $\begin{array}{l}\text { Hanley and Barbier } \\
\text { 2009; data from } \\
\text { literature, } \\
\text { questionnaires and } \\
\text { interviews }\end{array}$ \\
\hline (3) Scalability of market & $\begin{array}{l}\text { Scoring based } \\
\text { on the } \\
\text { available } \\
\text { markets }\end{array}$ & $\begin{array}{l}\text { For each market an additional point is } \\
\text { given (local, village, provincial, national } \\
\text { and international market) }\end{array}$ & $\begin{array}{l}\text { Data from questionnaires } \\
\text { and interviews }\end{array}$ \\
\hline (4) Acceptability to farmers & $\begin{array}{l}\text { Score reflects } \\
\text { the easy of } \\
\text { cultivation }\end{array}$ & $\begin{array}{l}\text { Includes the following criteria: the ease of } \\
\text { obtaining seedlings, the ease of } \\
\text { maintaining and harvesting, and the time } \\
\text { until the first harvest of the crop }\end{array}$ & $\begin{array}{l}\text { Data from questionnaires } \\
\text { and interviews }\end{array}$ \\
\hline
\end{tabular}

BPS Central Kalimantan 2018a, b; MoARI 2018, etc.). The general ecological and social attributes of the peatland crops assessed in this study are presented in Online Appendices 2 and 3 Supplementary Material. We were aware that there were ecological factors other than $\mathrm{CO}_{2}$ emissions, but for the scope of this study we were not able to assess the other indicators such as $\mathrm{CO}_{2}$ and $\mathrm{N}_{2} \mathrm{O}$ emissions from fertiliser application.

\section{Sustainability}

We used the typical water table depth of a crop when it was cultivated in peatland as the predictor for estimating the $\mathrm{CO}_{2}$ emissions of that crop, noting that in practice there were large variations in the water table depths of the crops. We grouped the crops into tree and non-tree crops (Ecocrop 2018). For both groups, we used a linear relationship between water table depth and carbon losses as specified in Table 1 above. We scored the sustainability of each crop based on the thresholds shown in Table 2, where 3 was the highest score and 0 (zero) was the lowest score. For comparison, when drained at 40 to $60 \mathrm{~cm}$, oil palm plantations released 36 to 60 tonnes $\mathrm{CO}_{2} /$ ha/year (Lim et al 2012).

\section{Profitability}

Profitability is assessed using Net Present Value (NPV) as an indicator (Hanley and Barbier 2009). For the NPV calculation of each crop, we use a discount rate of $10 \%$ and a discounting period of 25 years. Costs for acquiring the land are not included, i.e. it is assumed that smallholders have access to the land and do not need to pay a lease (which is the typical case for smallholders in Central Kalimantan). The costs include the investment costs (e.g. farmer tools, costs for seedling and initial land preparation) and operational costs (e.g. labour cost, fertiliser, pesticide/herbicide, irrigation/water 
Table 2 Score classification used to assess the sustainability performance of the peatland crops

\begin{tabular}{ll}
\hline Score & Description \\
\hline 3 & Peatland crop with estimated $\mathrm{CO}_{2}$ emissions ranging from 0 to $10 \mathrm{t} \mathrm{CO}_{2} \mathrm{ha}^{-1} \mathrm{year}^{-1}$ \\
2 & Peatland crop with estimated $\mathrm{CO}_{2}$ emissions ranging from 11 to $30 \mathrm{t} \mathrm{CO}_{2} \mathrm{ha}^{-1}$ year $^{-1}$ \\
1 & Peatland crop with estimated $\mathrm{CO}_{2}$ emissions ranging from 31 to $60 \mathrm{t} \mathrm{CO}_{2} \mathrm{ha}^{-1} \mathrm{year}^{-1}$ \\
0 & Peatland crop with estimated $\mathrm{CO}_{2}$ emissions more than $60 \mathrm{t} \mathrm{CO}_{2} \mathrm{ha}^{-1} \mathrm{year}^{-1}$ \\
\hline
\end{tabular}

management/monitoring, etc.). All money values have been converted to euro of the year 2017. We exclude the costs of restoring drained peatlands (e.g. costs for building dams to block drainage canals, see Hansson and Dargusch 2018)—assuming that these costs will not be paid by smallholders. The score classification for profitability is shown in Table 3. For comparison, the average expenditure on food and non-food per capita in Central Kalimantan province in 2017 was $€$ 888/year (BPS Central Kalimantan 2018a), and the NPV of the resource rent of oil palm production on peatland had been estimated at around $€ 40,000$ per hectare for a 25 years discounting period at a $10 \%$ discount rate (Sumarga and Hein 2015).

\section{Scalability of market}

We analysed the scalability of each crop by examining if it was (potentially) suitable for sale at the local (village), provincial, national and/or international market. We assessed the current markets where the crops were sold and then considered the potential for scaling up. Data were obtained from literature and supplemented by our questionnaires and interviews with the farmers and relevant stakeholders. We gave a score of 3 to crops which could be sold at local, provincial, national and international markets; a score of 2 to crops suitable for local, provincial and national markets; a score of 1 for crops with available markets at local and provincial levels; and a score of 0 (zero) for crops that could only be traded at the local (village) level, for instance because they were highly perishable or the demand for the products was very low outside of the village for example due to the availability of substitute crops that were cheaper or more preferable by the consumers. We acknowledged that there are local factors e.g. infrastructure that partly determined if and at what price crops could be exported from a village, and we also acknowledged that selling crops at international markets required production at a scale that was sometimes not feasible at the level of individual villages. Hence, our scoring should be seen as indicative, and we will elaborate on uncertainties in the discussion section.

\section{Acceptability to farmers}

We analysed the acceptability of the crops to the local farmers. Based on the stakeholder interviews, we assessed three aspects that were indicated by the farmers as potential bottlenecks to growing the crop: the ease of obtaining seedlings, the ease and costs for maintaining and harvesting the crop, and the time the farmer had to wait until the first harvest. With regard to the ease of obtaining seedlings and the ease of crop growing and harvest, we used a score of 1 for "easy" and score of 0 (zero) for "not easy". With regard to the time period until the first harvest, we gave a score of 1

Table 3 Score classification used to assess the profitability performance of the peatland crops

\begin{tabular}{ll}
\hline Score & Description \\
\hline 3 & Peatland crop with estimated NPV more than $€ 50,000$ \\
2 & Peatland crop with estimated NPV ranging from $€ 35,001$ to $€ 50,000$ \\
1 & Peatland crop with estimated NPV ranging from $€ 20,000$ to $€ 35,000$ \\
0 & Peatland crop with estimated NPV less than $€ 20,000$ \\
\hline
\end{tabular}


if the first harvest of the crop could be done in less than 2 years and a score of 0 (zero) if the crop needed more than 2 years to produce the first harvest. We then aggregated the scores from all components of cultivation to obtain a final score of the acceptability to the farmers for each particular crop, with 0 as the lowest and 3 as the highest overall score. We acknowledged that there were other relevant factors that are not considered such as risk of pest and diseases; however these are out of scope of the current study.

\section{Results}

Sustainability

Table 4 shows the estimates of the $\mathrm{CO}_{2}$ emissions and the resulting score for 15 food crop species commonly cultivated in the peatland areas of Central Kalimantan.
Note that some crops (e.g. sweet melon, bitter gourd, pineapple) were grown using a ridge and furrow system, where seedlings are planted in the ridges. These ridges were drier and therefore subject to more oxidation. The impact of the ridges on $\mathrm{CO}_{2}$ emissions as well as the effects of fertiliser use (which may enhance microbial activity and thereby emissions of $\mathrm{CO}_{2}$ and $\mathrm{N}_{2} \mathrm{O}$ ) were not considered in our analysis and ranking should be considered as indicative given that there were differences in the degree to which ridges and furrows are used and fertilisers were applied between crops and between villages. We also did not consider the effects of fire use in smallholder farming. The use of fire for burning crop residues is now prohibited in Central Kalimantan, and data show that crop residue burning has decreased in the past years (Surahman et al. 2019). It is applied in particular for paddy and other annual crops, and less relevant for the perennials in Table 4.

Table $4 \mathrm{CO}_{2}$ emissions and sustainability scores for food crops cultivated in the peatland areas of Central Kalimantan

\begin{tabular}{|c|c|c|c|c|}
\hline Type of food crop & Group & $\begin{array}{l}\text { Water table depth (meter below peat } \\
\text { surface) }\end{array}$ & $\begin{array}{l}\text { Estimated } \mathrm{CO}_{2} \text { emissions ( } \mathrm{t} \mathrm{CO}_{2} / \\
\text { ha/year) }\end{array}$ & Score \\
\hline Sago palm/sagu (Metroxylon sagu) & Tree & 0 & 0 & 3 \\
\hline Illipe nut/tengkawang (Shorea $\mathrm{spp}$.) & Tree & 0 & 0 & 3 \\
\hline $\begin{array}{l}\text { Water spinach/kangkong (Ipomoea } \\
\text { aquatica) }\end{array}$ & $\begin{array}{l}\text { Non- } \\
\text { tree }\end{array}$ & 0 & 9 & 3 \\
\hline $\begin{array}{l}\text { Kelakai/edible fern (Stenochlaena } \\
\text { palustris) }\end{array}$ & $\begin{array}{l}\text { Non- } \\
\text { tree }\end{array}$ & 0 & 9 & 3 \\
\hline $\begin{array}{l}\text { Snake fruit/salak (Salacca/Eleiodoxa } \\
\text { sp.) }\end{array}$ & Tree & -0.2 & 20 & 2 \\
\hline Durian (Durio zibethinus) & Tree & -0.3 & 29 & 2 \\
\hline $\begin{array}{l}\text { Mangosteen/manggis (Garcinia } \\
\text { mangostana) }\end{array}$ & Tree & -0.3 & 29 & 2 \\
\hline Rambutan (Nephelium lappaceum) & Tree & -0.3 & 29 & 2 \\
\hline Banana/pisang (Musa paradisiaca) & $\begin{array}{l}\text { Non- } \\
\text { tree }\end{array}$ & -0.3 & 34 & 1 \\
\hline $\begin{array}{l}\text { Dragon fruit/buah naga (Hylocereus } \\
\text { undatus) }\end{array}$ & $\begin{array}{l}\text { Non- } \\
\text { tree }\end{array}$ & -0.3 & 34 & 1 \\
\hline Sweet melon/melon (Cucumis melo) & $\begin{array}{l}\text { Non- } \\
\text { tree }\end{array}$ & -0.3 & 34 & 1 \\
\hline $\begin{array}{l}\text { Bitter gourd/pare (Momordica } \\
\text { charantia) }\end{array}$ & $\begin{array}{l}\text { Non- } \\
\text { tree }\end{array}$ & -0.3 & 34 & 1 \\
\hline Pineapple/nanas (Ananas comosus) & $\begin{array}{l}\text { Non- } \\
\text { tree }\end{array}$ & -0.3 & 34 & 1 \\
\hline $\begin{array}{l}\text { Candlenut/kemiri (Aleurites } \\
\text { moluccana) }\end{array}$ & Tree & -0.5 & 49 & 1 \\
\hline $\begin{array}{l}\text { Liberica coffee/kopi liberika (Coffea } \\
\text { liberica) }\end{array}$ & Tree & -0.5 & 49 & 1 \\
\hline
\end{tabular}


These 15 crops emit less than 50 tonnes $\mathrm{CO}_{2} / \mathrm{ha} /$ year depending upon the species, group and the water table. The paludiculture crops sago and illipe nut are capable to generate zero $\mathrm{CO}_{2}$ emissions. Two vegetables cultivated with a zero water table, i.e. kelakai edible fern (Stenochlaena palustris) and water spinach, still produce minor $\mathrm{CO}_{2}$ emissions due to the absence of shade provided by trees (Hooijer et al. 2012). In this study candlenut and liberica coffee show the highest $\mathrm{CO}_{2}$ emissions, but still do not lead to significant $\mathrm{CO}_{2}$ emission, fire risk and soil subsidence reduction compared to oil palm grown with high water tables. Various fruit trees (snake fruit, durian, mangosteen, rambutan) can be grown with relatively limited drainage $(30 \mathrm{~cm})$, provide shade and compared to oil palm they have a longer life cycle (meaning fewer years without tree cover). It may also be that they can be grown with lower fertiliser inputs compared to oil palm, and hence lead to an even larger reduction of $\mathrm{CO}_{2}$ emissions (since fertilisers stimulate microbial activity contributing to peat oxidation), but this needs to be examined further. Hence, fruit trees are considerably more sustainable then oil palm, but will still lead to some $\mathrm{CO}_{2}$ emission and subsidence.
Profitability

The estimated Net Present Value (NPV) and the score for the profitability of each crop are presented in Fig. 2. The values were converted into euro $(€)$ based on the year 2017 average exchange rate of IDR 15,270 or US\$ 1.10 for $€ 1$ according to European Central Bank (ECB 2018).

Our analysis showed that three crops had NPVs of more than $€ 40,000 /$ ha (and were comparable to oil palm in terms of profitability), i.e. dragon fruit, candlenut and mangosteen. Candlenuts were already in high demand on local markets as they were used for spice and seasoning in the Indonesian cuisine (reaching their peak prices during religious celebrations in Indonesia including Eid-al-Fitr and Christmas). Dragon fruits were popular because of their health and decorative benefits so they could become alternative ingredient for sherbet and food colouring agent (PROSEA 2018). Dragon fruit had been considered as agriculture option on peatland (UNDP Indonesia 2017), but growing the fruit still required some drainage and therefore would ultimately not be sustainable. In addition, the stability and scalability of the market was more limited compared to, for instance, banana and sweet melon, which were grown already in sizeable volumes on shallow peat in Central Kalimantan. Mangosteen had a widely appreciated

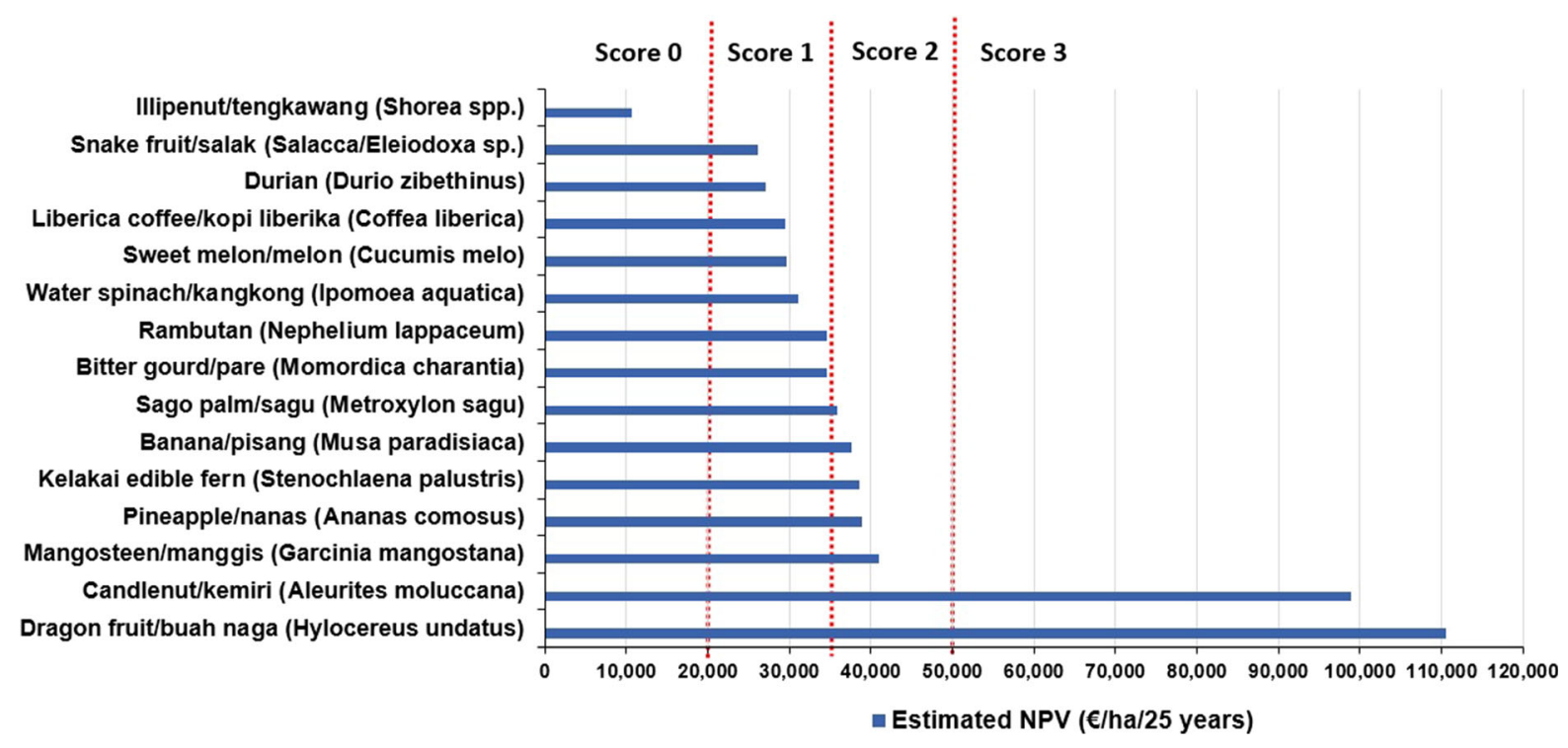

Fig. 2 The estimation of the NPVs per hectare for 25 years and the profitability scores for 15 food crops grown in the peatland areas of Central Kalimantan 
taste, however it was somewhat perishable. Illipe nut, snake fruit and durian had a relatively low profitability which related to the revenues they generated once mature and the time farmers had to wait until the first harvest. Illipe nuts were typically harvested just once in every 4 years. In a given area illipe trees tended to have a synchronised time of flowering and maturing of the nuts, which meant that the local supply would be highly irregular. This posed a challenge for processing the fruits, which was one of the reasons why illipe nuts were not cultivated at a significant scale in Kalimantan. Furthermore, there are several different species that are at present labelled as illipe nuts with different productivity, oil quality and yield variability. Central Kalimantan is also an important producer of water spinach (BPS Central Kalimantan 2018a, b), which can be grown under undrained conditions. Sago is an interesting species, sago starch is used both as food product and could potentially be used for bioplastic production. Once mature, sago coppices, and trees can be harvested for many decades at low cost and generating relatively high revenue (up to 1500 euro/ ha/year, if well maintained). However, the sago palm needs to grow 8 to 12 years before the first harvest can take place (TECA 2015), which reduces the NPV of new stands (and it becomes a barrier to farmers as examined below).

\section{Scalability of the market}

Table 5 presents the availability of the market and the score of the scalability of the market for each food crop species analysed in this study.

Our analysis revealed that every crop was traded by farmers in at least one village with some products were also marketed across the regencies/districts in Central Kalimantan or to other provinces. Our respondents also mentioned that there was no direct trading of their products to other parts of Indonesia or international markets yet. However, we consider that there is a potential demand for several crops in other Indonesian markets in particular Java, and that banana, pineapple, sweet melon, illipe nut oil (also used in cosmetics) and sago starch can potentially be traded in international markets. Provided that these crops can be grown at scale and supply chains can be established, scaling up to international markets is then possible (BPS Central Kalimantan 2018b; BPS 2018b). Stenochlaena palustris (kelakai/midin vegetables) are popular in the local cuisines in Borneo (Nion et al. 2018; Chai 2016). However, kelakai vegetables are difficult to market outside local markets because of their short shelf life (leaves will begin to turn black after $24 \mathrm{~h}$, even if they are stored in refrigerators) unless a better packaging system is invented.

\section{Acceptability to farmers}

Table 6 shows the acceptability of the 15 food crops to farmers in Central Kalimantan based on the ease of cultivation of these crops. Important aspects are the time that the farmer needs to wait before he can get his first income, the ease of access to (high yielding) seedlings and the ease of maintenance and harvesting.

Most of the peatland farmers in Central Kalimantan in our survey stated that seedlings of most crops are relatively easy to obtain from local sources, although in some cases they had to buy higher quality seedlings at local or provincial markets. In the case of harvesting, only manual (traditional) techniques were used by the farmers as there was little mechanisation. Heavy equipment is also not suitable for peatland, particularly in undrained conditions. In 2017, water spinach was one of the vegetable crops with the largest harvested areas in Central Kalimantan (BPS Central Kalimantan 2018a; MoARI 2018). Among the perennial fruits, rambutan, durian and banana are widely grown in Central Kalimantan (MoARI 2018). Edible fern is a wild-growing species that can be cultivated without any agricultural treatment. However, this plant is often considered by the farmers as a weed despite its potential profit to be sold as a vegetable. Sago palms are naturally ubiquitous in Central Kalimantan. Sago starch, extracted from the stem of the plant, was used as a staple food in the area before it was replaced by rice. They can be easily cultivated in shallow and medium depth peat, as well as on the riverbanks by planting the suckers (Tata and Susmianto 2016). Tree crops (mostly fruit trees) generally require several years before the time of the first harvest, up to 8 to 12 years for sago. Hence, farmers should intercrop these crops with other annual crops, livestock and/or fish culture in the first years in order to increase income. This income was not considered in this study and might increase both the NPV and the acceptability to farmers of woody crops. 
Table 5 The scalability of the market for 15 food crops from Central Kalimantan peatlands

\begin{tabular}{|c|c|c|c|c|c|}
\hline \multirow[t]{2}{*}{ Type of food crop and product } & \multicolumn{4}{|c|}{ Market availability } & \multirow[t]{2}{*}{ Score } \\
\hline & Local (Village) & Provincial & National & International & \\
\hline Sago palm/sagu/Metroxylon sagu (wet sago) & 1 & 1 & 1 & 1 & 3 \\
\hline Illipe nut/tengkawang/Shorea spp. (nut) & 1 & 1 & 1 & 1 & 3 \\
\hline Sweet melon/melon/Cucumis melo (fruit) & 1 & 1 & 1 & 1 & 3 \\
\hline Pineapple/nanas/Ananas comosus (fruit) & 1 & 1 & 1 & 1 & 3 \\
\hline Banana/pisang/Musa paradisiaca (fruit) & 1 & 1 & 1 & 1 & 3 \\
\hline Dragon fruit/buah naga/Hylocereus undatus (fruit) & 1 & 1 & 1 & 0 & 2 \\
\hline Durian/Durio zibethinus (fruit) & 1 & 1 & 1 & 0 & 2 \\
\hline Mangosteen/manggis/Garcinia mangostana (fruit) & 1 & 1 & 1 & 0 & 2 \\
\hline Rambutan/Nephelium lappaceum (fruit) & 1 & 1 & 1 & 0 & 2 \\
\hline Snake fruit/salak/Salacca (Eleiodoxa) sp. (fruit) & 1 & 1 & 1 & 0 & 2 \\
\hline Liberica coffee/kopi liberika/Coffea liberica (drained bean) & 1 & 1 & 1 & 0 & 2 \\
\hline Water spinach/kangkong/Ipomoea aquatica (vegetable) & 1 & 1 & 0 & 0 & 1 \\
\hline Bitter-gourd/pare/Momordica charantia (vegetable) & 1 & 1 & 0 & 0 & 1 \\
\hline Candlenut/kemiri/Aleurites moluccana (nut) & 1 & 1 & 0 & 0 & 1 \\
\hline Kelakai/edible-fern/Stenochlaena palustris (vegetable) & 1 & 0 & 0 & 0 & 0 \\
\hline
\end{tabular}

\section{Overall assessment}

Figure 3 shows the aggregated scores of each food crop on sustainability, profitability, scalability of market and acceptability to the farmers in Central Kalimantan. Sago palm, banana and pineapple have the highest scores, whereas liberica coffee has the lowest score. Sago palm and illipe nut have the highest scores for both sustainability and scalability of market, whereas banana, pineapple and sweet melon have the highest scores in term of the scalability of market and acceptability to farmers (and indeed these crops are increasingly grown on peatlands in Central Kalimantan). Mangosteen scores well on all indicators and dragon fruit is particularly profitable. Water spinach and kelakai edible fern have the highest scores for both sustainability and acceptability to farmers.

\section{Discussion}

Data uncertainties and limitations

It is clear that there are uncertainties related to the scoring of each crop. We score each indicator by crop based on integrated assessment of literature, expert knowledge and stakeholder engagement. However, in reality there were differences between sites, as a function of local environmental and socio-economic characteristics, which were not considered in this study. For example, profitability for smallholders was depending upon the local prices, which might vary considerably between areas (and season). In addition, our emission factors assumed a certain drainage level per crop, but in practice each crop was grown under a range of drainage conditions. Where peatlands were already drained before planting by smallholders, it was unlikely that farmers would increase the water levels to the maximum level that the crop could sustain (see also Giesen and Nirmala 2018). We had noted in several villages that many crops, for example rambutan, durian, dragon fruit, pineapple and melon, were sometimes grown at deeper water tables than assumed in our study (water spinach was an exception as it required near sub-merged condition). Furthermore, there was variation in the degree to which fertilisers and nutrients were locally used, and in this study we did not account for their effect in speeding up decomposition contributing to $\mathrm{CO}_{2}$ and $\mathrm{N}_{2} \mathrm{O}$ emissions (Leifeld and Menichetti Joosten et al. 2016; Osaki et al. 2016). Hence, our scoring should be seen as indicative yet useful in terms of assessing the 
Table 6 The acceptability of selected peatland crops to farmers in Central Kalimantan

\begin{tabular}{|c|c|c|c|c|c|}
\hline \multirow[t]{2}{*}{ Type of food crop } & \multirow[t]{2}{*}{$\begin{array}{l}\text { The ease of obtaining } \\
\text { seedlings }\end{array}$} & \multirow[t]{2}{*}{$\begin{array}{l}\text { The ease of maintaining and } \\
\text { harvesting }\end{array}$} & \multicolumn{2}{|c|}{$\begin{array}{l}\text { Time period until } \\
\text { the first harvest }\end{array}$} & \multirow[t]{2}{*}{ Score } \\
\hline & & & $\begin{array}{l}< \\
2 \text { year }\end{array}$ & $\begin{array}{l}> \\
2 \text { year }\end{array}$ & \\
\hline Pineapple/nanas (Ananas comosus) & Easy (1) & Easy (1) & $\boldsymbol{\nu}(1)$ & & 3 \\
\hline Sweet melon/melon (Cucumis melo) & Easy (1) & Easy (1) & $\boldsymbol{V}(1)$ & & 3 \\
\hline Banana/pisang (Musa paradisiaca) & Easy (1) & Easy (1) & $\boldsymbol{V}(1)$ & & 3 \\
\hline $\begin{array}{l}\text { Water spinach/kangkong (Ipomoea } \\
\text { aquatica) }\end{array}$ & Easy (1) & Easy (1) & $\boldsymbol{V}(1)$ & & 3 \\
\hline $\begin{array}{l}\text { Bitter gourd/pare (Momordica } \\
\text { charantia) }\end{array}$ & Easy (1) & Easy (1) & $\boldsymbol{V}(1)$ & & 3 \\
\hline $\begin{array}{l}\text { Kelakai/edible fern (Stenochlaena } \\
\text { palustris) }\end{array}$ & Easy (1) & Easy (1) & $\boldsymbol{V}(1)$ & & 3 \\
\hline $\begin{array}{l}\text { Dragon fruit/buah naga (Hylocereus } \\
\text { undatus) }\end{array}$ & Difficult (0) & Easy (1) & $\boldsymbol{V}(1)$ & & 2 \\
\hline $\begin{array}{l}\text { Mangosteen/manggis (Garcinia } \\
\text { mangostana) }\end{array}$ & Easy (1) & Easy (1) & & $\boldsymbol{V}(0)$ & 2 \\
\hline $\begin{array}{l}\text { Snake fruit/salak (Salacca/Eleiodoxa } \\
\text { sp.) }\end{array}$ & Easy (1) & Easy (1) & & $\boldsymbol{V}(0)$ & 2 \\
\hline Illipe nut/tengkawang (Shorea spp.) & Easy (1) & Easy (1) & & $\boldsymbol{V}(0)$ & 2 \\
\hline Rambutan (Nephelium lappaceum) & Easy (1) & Easy (1) & & $\boldsymbol{\nu}(0)$ & 2 \\
\hline Sago palm/sagu (Metroxylon sagu) & Easy (1) & Difficult (0) & & $\boldsymbol{V}(0)$ & 1 \\
\hline Durian (Durio zibethinus) & Easy (1) & Difficult (0) & & $\boldsymbol{V}(0)$ & 1 \\
\hline $\begin{array}{l}\text { Candlenut/kemiri (Aleurites } \\
\text { moluccana) }\end{array}$ & Difficult (0) & Easy (1) & & $\boldsymbol{V}(0)$ & 1 \\
\hline $\begin{array}{l}\text { Liberica coffee/kopi liberika (Coffea } \\
\text { liberica) }\end{array}$ & Difficult (0) & Easy (1) & & $\boldsymbol{V}(0)$ & 1 \\
\hline
\end{tabular}

barriers to the cultivation of the individual paludiculture and non-paludiculture crops in the peatlands.

Another important limitation of our study is that we assessed the crops in isolation whereas in reality the smallholder farmers often plant a combination of crops in order to spread risks, diversify income and spread food availability throughout the year. Intercropping might reduce some of the disadvantages of planting individual crops. For example, sago could be grown in combination with vegetables that could provide an income early in the cropping cycle. On the other hand, intercropping might increase $\mathrm{CO}_{2}$ emission as farmers often create ridges to accommodate crops that need dryland. We also excluded non-food crops such as jelutung resin (Dyera sp.) which could be grown as industrial plantations without draining the peatlands (Giesen and Nirmala 2018). Hence, opportunities for promoting sustainable livelihoods in peatlands are larger than what we present in this paper.

Restoring the degraded peatland for paludiculture incurs costs for hydrological restoration and revegetation, which may range from US\$400/ha to US $\$ 25,000 /$ ha depending on the level of degradation (Hansson and Dargusch 2018). As mentioned previously, these costs were not considered in our analysis. Given the national and international significance of the health and environmental impacts of peatland drainage, and given that the drainage was in most cases not started by local people, it seems reasonable to assume that local smallholders would not bear the costs of peat restoration. Indeed, at the moment, the Government of Indonesia is pursuing peatland restoration funded from the national budget. Other opportunities for funding restoration relate to (national and/or international) 


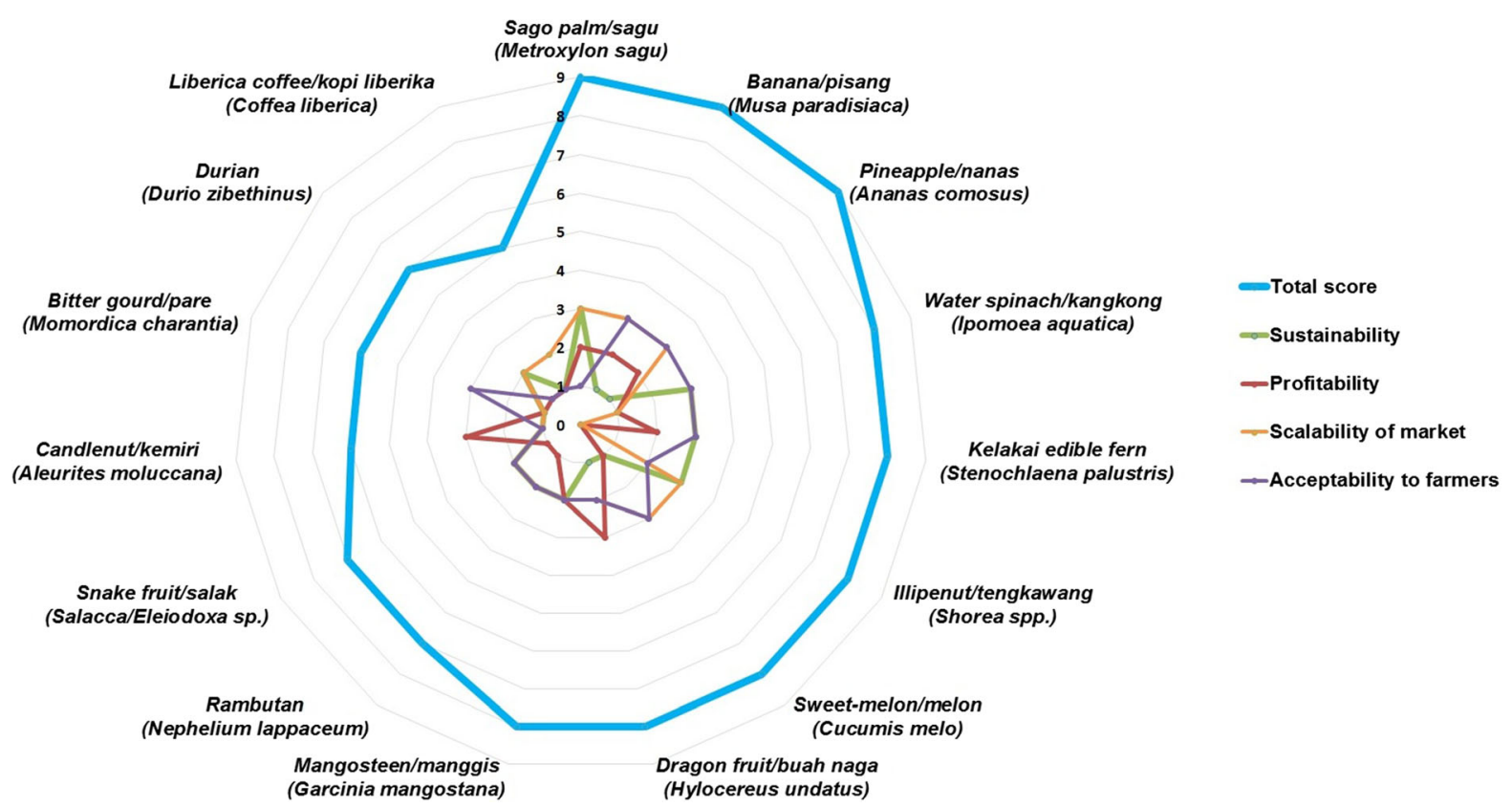

Fig. 3 Results of the aggregated scores of the socio-ecological indicators for 15 food crops from Central Kalimantan peatlands

carbon credits. However, in many cases, peatland restoration can only be successful if followed by profitable peatland use which provides local incentives for controlling fires and abstaining from renewed drainage. These incentives will require some forms of paludiculture.

Opportunities and bottlenecks for paludiculture development on peatland areas

In Central Kalimantan, the conversion of peat to croplands and plantations is still ongoing. To illustrate this trend, in the year 2000 around 144,500 ha of peatlands was used for cropping and this increased to 241,408 ha in 2014 (an increase of 40\%). In 2017, this increased to 702,408 ha, which was nearly a fivefold increase in 17 years (Uda et al. 2017; MoEFRI 2018). In 2017 , the total area of protected peatland only covered about $55 \%$ of the total area of peat hydrological units (PHU or Kawasan Hidrologi Gambut/KHG) in Central Kalimantan (MoEFRI 2018). A crucial element for better managing Indonesian peatlands is to stop the ongoing conversion of peatlands. Drainage always leads to high $\mathrm{CO}_{2}$ emissions, and, once drained, the rewetting of peatland (which is done through a mix of canal blocking, fire control and rehabilitation of the vegetation) is a very difficult and expensive task (Hansson and Dargusch 2018; BRG 2019).

Whilst more regulations are in place nowadays for plantation companies, there are currently little controls and support mechanisms for smallholder farmers. Smallholders would need to be supported with the planting of crops that require no or limited drainage. In this study, we focus on food crops. Seven crops are tolerant to at least temporary inundation (e.g. sago palm, illipe nut, water spinach, kelakai edible fern, banana, snake fruit, mangosteen) while others warrant strict water management or limited drainage. Some crops are not recommended for scaling-up to plantation-based systems because there is only a limited market for them (e.g. bitter gourds, water spinach, kelakai edible fern). Therefore, in a landscape approach to peat management, it is important to separately assess the recommended species for the farmers/communities and the plantations (Giesen 2013). In our paper, we focus on the communitybased farming. We find that peatland uses by indigenous farmers are mostly a long continued heritage (e.g. durian, rambutan, illipe nut, mangosteen) while other ethnic farmers (e.g. transmigrants from Java, Bali or Sumatra) tend to be somewhat more open to introduce new crops such as dragon fruit, snake fruit, sweet melon, liberica coffee, candlenut, etc. in the peatlands. 
Further insights into the opportunities and barriers for the cultivation of paludiculture food crops are presented in Online Appendix 4 Supplementary Material.

We found that market demand and access to market were the most important factors for farmers in choosing the crops. Currently, crops are grown, in particular, for local village markets with some crops traded on provincial markets, e.g. in Palangka Raya, the province's capital. There are no connections to international markets yet, and there are several obstacles to scaling up production. First, villages are spread over large areas and each village only has a limited production capacity. Second, infrastructure in many parts of the province is still relatively poor. Third, technology and facilities to help local farmers maintaining, harvesting and processing their crops are still lacking. Before their export ban in 2012, illipe nuts were in high demand in international markets. The ban was meant to encourage the development of downstream industry, as also expected with the export ban of raw rattan (MOTRI 2012), but until now the development of the downstream sector has not yet occurred. Another obstacle to the export of food products is that products often do not meet the standards required for export (Moïsé et al. 2013). Thus, scaling up should involve establishing supply chains, linking traders to markets and support for farmers to enhance the quality of their produce. It may be most practical to first focus on scaling up to national markets before promoting export.

Some regencies in our study area have already developed a number of community trials for crops in the peatland restoration areas (e.g. sago in Pulang Pisau regency, dragon fruit in Palangka Raya), and have initiated some new plantation trials (e.g. philippine-tung/kemiri sunan (Reutealis trisperma), tamanu/nyamplung (Calophyllum inophyllum) plantations in Palangka Raya, Pulang Pisau regency and Katingan regency) (CIFOR 2016). These trials showed that these crops could grow well in degraded and burned peatlands, including in agroforestry systems as well (Maimunah et al. 2018).

We also note that swamp rice farming may be an alternative opportunity in the (degraded) peatlands in Indonesia (Surahman et al. 2018) as there are some recommended rice varieties which are adaptive to peatlands conditions (e.g. Inbrida Padi Rawa/Impara, IR42, IR64, IR66, Kapuas, etc.) (JICA 2017). Nevertheless, rice farming may not be practical in many peatland areas in Central Kalimantan given the specific requirements for water level control and tillage, soil amelioration and fertilisation. Furthermore, the market price of the swamp rice varieties is often lower than the market price of local rice varieties grown on mineral soil (e.g. Siam unus, Lemo, and Pandak) because local communities prefer the taste of these local rice varieties (in line with Surahman et al. 2018; Noor et al. 2014). Finally, rice cultivation still requires drainage during part of the season and is in that sense also not a true paludiculture crop (Noor et al. 2014; Giesen and Nirmala 2018). For these various reasons we hypothesise that swamp rice may have limited potential in Central Kalimantan, but we acknowledge that swamp rice may potentially be more suitable in other provinces.

We believe that sago is a particularly promising paludiculture crop. The market is potentially very large as sago can be used for local and national food production and can also be turned into starch for export, or be used to produce bioplastic and bioethanol (Nishimura 2018). In principle, Indonesia can produce the raw material for plastic bags and other packaging materials both for national use and for export from domestically grown sago in peat, thereby resolving two major challenges (peat degradation and marine and coastal plastic pollution) in one go. Sago also has other applications: different parts of sago palm can be used for food (the young stems can be cooked), construction and weaving crafts materials, food pellets ingredients for poultry and fishery farms, biomass (ethanol made from sago), growing media for Volvariella volvacea mushrooms and breeding Rhynchophorus larvae which is a good source of protein (JICA 2017). Cultivation of sago in Riau is already locally very profitable, with revenues from mature sago stands of up to 1500 euro per ha per year (Orentlicher 2019). However, a main factor that might hinder farmers to cultivate sago palm is the time to wait before the first crop can be harvested (at least 8 years but sometimes up to 12 years; TECA 2015). Once the sago is mature harvesting can take place every year and unlike oil palm there is no need to replant after 25 years or so. Sago grows well in undrained, shallow peat (up to $3 \mathrm{~m}$ ) but is less productive in deeper peat. Hence, it is urgent that: (i) we examine how sago productivity can also be maintained in deep peat; (ii) fast growing sago varieties are developed; (iii) cropping systems are 
developed that combine growing sago with intercropping in the first 8 years or so; (iv) we examine if and how farmers (or plantation companies) can get financial or other support to overcome the period of 8 years with less income (e.g. in the form of carbon credits or government subsidies); and (v) there is further testing of the potential to use sago for various non-food applications in particular bioplastic and bioethanol.

\section{Policy recommendations}

The Indonesian Government has been promoting the protection and sustainable management of peatland ecosystems through a number of regulations including the 2016 National Government regulation PP No. 57 on peatland ecosystems protection and management (Indonesia Government Regulation 2016). The government has prescribed $3 \mathrm{~m}$ peat depth as the main criterion for distinguishing between protected and development peatland areas and a water table of deeper than $0.4 \mathrm{~m}$ as the criterion for damaged peatland area. Issues remain with regards to implementation and enforcement of the regulation, identifying where the boundaries between deep and shallow peat are, and dealing with the hydrological connectivity within peat domes as draining shallow peat may also affect deeper peat layers in the same peat dome. In addition the externalities from draining peat between 1 and $3 \mathrm{~m}$ are similar in scope and magnitude as those in deeper peat, except for the shorter time period during which they occur before the peat has disappeared.

Compared to the "traditional"-drainage-requiring crops (such as oil palm, acacia, and rubber), paludiculture crops are currently less attractive to farmers either because of lower profitability, limited market opportunities or more complex farming requirements (see also Joosten et al. 2016; Sumarga et al. 2016; Giesen and Nirmala 2018). The adoption of paludiculture will therefore depend greatly upon policies and regulations imposed by the Indonesian government. A potential way forward is to ban the planting of oil palm on all peatlands (hence including shallow peat), and to provide support for paludiculture in degraded peatlands by promoting local trials, farmer visits to these trials, farming training and making seedlings available to farmers. The barriers described in the previous section are very different for each of the paludiculture crops. The promotion of paludiculture needs to consider these barriers to fine-tuning the technical support to farmers. Options specific for different crops include providing post-harvest technology to farmers to increase product quality; training and support for establishing facilities for local processing of foods (e.g. sago noodles, banana chips, etc.) and financial support for farmers planting crops which need a longtime period before the first harvest (such as sago). We provide further details in Online Appendix 5 Supplementary Material.

We also believe the export bans on raw illipe nuts and rattan should be revoked as soon as possible. Local farmers had long been cultivating illipe nuts due to high demand in the international markets until the export ban in 2012. Rattan is a profitable crop (before the export ban) that can be grown as an understorey species in peatland forests without drainage and as an understorey crop in secondary forests (Sumarga et al. 2015). The bans on the export of illipe nuts and rattan have been in place for 8 years (MoTRI 2012) but there are still no signs of domestic illipe nuts and rattan industries emerging while the ban suppresses the illipe nuts and rattan prices and thereby the income of farmers who are protecting the peatland forest through their illipe nuts cultivation and rattan farming.

Note that, in addition to supporting farming activities, there is also a need to look at peat domes in an integrated manner, particularly in terms of maintaining high water levels across the domes. Large plantation companies operating in peatland generally manage water levels within their own plantations. However, ensuring effective water management is also a major issue for smallholder farmers as individual farmers only have limited means to control the water levels in their fields. Water management, including in peat domes, fall under the Ministry of Public Works, and their support is essential in ensuring a transition to paludiculture, particularly in relation to the rehabilitation and sustainable use of peat for smallholder cropping.

It is important that more efforts to introduce, test, develop and scale up paludiculture crops are started as soon as possible. It is a major undertaking to rehabilitate millions of hectares of degraded peatlands and, over time, to replace oil palm on peat by other profitable crops that can be grown on peat without drainage (or with low drainage). Shifting towards profitable, inclusive and sustainable peatland management involves steering the investment and land management decisions in both plantation companies 
and smallholders in such a way that further drainage is avoided and there is a gradual replacement of crops that require drainage with the crops that can grow in the peatland without drainage. A main bottleneck in this effort is a lack of options to replace oil palm by other profitable and sustainable crops suitable for peatland. Local contexts may provide opportunities for different paludiculture crops, depending upon for instance access and proximity to markets, seeds availability, farmers' preferences, etc. Paludiculture crops may also generate profits through carbon trading which, in turn, will support Indonesia to achieve its national contribution to the Paris Agreement (i.e. to reduce its GHG emissions up to $29 \%$ by 2030 (INDC 2015). In this context, it is important that the communities as well as the regencies/districts that have successfully managed their peatlands are recognised and rewarded for their contributions to sustainably maintain the peatlands. A fiscal policy that integrates ecological and social aspects into the intergovernmental fiscal transfer instruments should be considered to promote and support the sustainable development in peatland areas (e.g. provide generalpurpose transfer (Dana Alokasi Umum, DAU), specific-purpose fund (Dana Alokasi Khusus, DAK), and/or shared revenue fund from taxes, non-taxes and/or natural resources (Dana Bagi Hasil, DBH)) (Cadman et al. 2019). Lastly, it is crucial to keep and better enforce the existing policy of "no drainage" on the peatlands, extending this to shallow peat. It is already a major and increasing challenge to deal with the continued subsidence and fires in currently drained peatland (Hooijer and Vernimmen 2013).

\section{Conclusions}

This study assesses 15 paludiculture and non-paludiculture food crops that are grown in peatland areas in Indonesia in terms of sustainability, profitability, scalability of market and the acceptability to the farmers. It is important to identify suitable paludiculture crops for Indonesian peatlands given the high $\mathrm{CO}_{2}$ emissions, fire risks and associated health impacts that are characteristic of the current peat management practices. All crops assessed in this study can be grown with no drainage or water table depth above $0.5 \mathrm{~m}$ drainage, with $\mathrm{CO}_{2}$ emissions ranging from 0 to 49 tonnes $\mathrm{CO}_{2} / \mathrm{ha} / \mathrm{year}$. Not all of these crops are therefore paludiculture crops, and priority should be given to rehabilitate peatlands with crops that do not require any drainage (as identified in Table 4 above). There are major differences in the profitability between crops (which to certain crops also depend on the government policies) that will strongly affect their acceptability to farmers. The most promising crops are sago, illipe nuts and mangosteen which, in principle, are able to compete with oil palm. A specific barrier to their large scale introduction is that it takes a number of years for the crops to become productive which in the case of sago and illipe nuts could take up to 8 years. This is for many smallholder farmers too long to wait for a return on their investment, and government support should be considered. Other species that can be of interest to local farmers are banana, pineapple water spinach, kelakai edible fern, dragon fruit, and sweet melon, even though some of these crops still require some drainage. Sago and illipe nuts are highly potential crops but only if policy and technical supports for farmers can be provided to properly harvest, process and market the crops. The results of this study can be used as inputs to policy making, business plans, and value chain development programmes for a sustainable peatland management. Critical factors in promoting paludiculture crops are enhancing the enforcement of legislation regulating sustainable peatland use; extending the ban on peatland conversion and drainage of shallow peat (where some of the paludiculture crops in particular sago are a viable alternative for oil palm); and further supports for farmers growing paludiculture crops for example by testing new processing techniques (e.g. for biofuels or processed food products), and marketing their produce to national and international markets.

Acknowledgements The authors gratefully thank the government officials, experts, farmers and all respondents in Central Kalimantan for their contributions and help in conducting this research. We also sincerely acknowledge the Governor of Central Kalimantan Province for giving permission to access the relevant data in Central Kalimantan's provincial institutions. First author gratefully acknowledges the Lembaga Pengelola Dana Pendidikan/LPDP (Indonesia Endowment Fund for Education) for providing the scholarship and financial support for this study. The authors would like to thank the reviewers for their helpful comments.

Open Access This article is licensed under a Creative Commons Attribution 4.0 International License, which permits use, sharing, adaptation, distribution and reproduction in any medium or format, as long as you give appropriate credit to the 
original author(s) and the source, provide a link to the Creative Commons licence, and indicate if changes were made. The images or other third party material in this article are included in the article's Creative Commons licence, unless indicated otherwise in a credit line to the material. If material is not included in the article's Creative Commons licence and your intended use is not permitted by statutory regulation or exceeds the permitted use, you will need to obtain permission directly from the copyright holder. To view a copy of this licence, visit http://creativecommons.org/licenses/by/4.0/.

\section{References}

BPS (2018a) Statistical year book of Indonesia 2018. Badan Pusat Statistik (BPS) Statistics Indonesia, Jakarta

BPS (2018b) Statistics of annual fruit and vegetables plants Indonesia 2017. Badan Pusat Statistik (BPS) Statistics Indonesia, Jakarta

BPS Central Kalimantan (2018a) Statistical year book of Central Kalimantan 2017. Badan Pusat Statistik (BPS) Central Kalimantan Statistics Central Kalimantan, Indonesia, Jakarta

BPS Central Kalimantan (2018b) Statistics of annual fruit and vegetables plants Central Kalimantan 2017. Badan Pusat Statistik (BPS) Central Kalimantan Statistics Central Kalimantan, Indonesia, Jakarta

BRG (2018) Badan Restorasi Gambut. In: Peta Restorasi. The Peatland Restoration Agency of the Republic Indonesia. https://brg.go.id/wp-content/uploads/2017/03/BRG_PetaRestorasi-Kalteng.pdf. Accessed 9 Aug 2018

BRG (2019) Badan Restorasi Gambut. In: Profil Desa Peduli Gambut Kalimantan Tengah Tahun 2017 dan 2018. The Peatland Restoration Agency of the Republic Indonesia. https://brg.go.id/desa-peduli-gambut/. Accessed $27 \mathrm{Apr}$ 2019

Cadman T, Sarker T, Muttaqin Z, Nurfatriani F, Salminah M, Maraseni T (2019) The role of fiscal instruments in encouraging the private sector and smallholders to reduce emissions from deforestation and forest degradation: evidence from Indonesia. For Policy Econ. https://doi.org/10. 1016/j.forpol.2019.04.017

CIFOR, Catriona Croft-Cusworth (2016) Menanam Sumber Energi Baru. https://forestsnews.cifor.org/45888/ menanam-sumber-energi-baru?fnl=id. Accessed 11 July 2018

Chai PPK (2016) Midin (Stenochlaena palustris), the Popular Wild Vegetable of Sarawak. Utar Agric Sci J 2:18-20

Dohong A, Abdul Aziz A, Dargusch P (2018) A review of techniques for effective tropical peatland restoration. Wetlands 38(2):275-292. https://doi.org/10.1007/s13157018-1017-6

ECB (2018) European Central Bank: Euro foreign exchange reference rates. https://www.ecb.europa.eu/stats/policy_ and_exchange_rates/euro_reference_exchange_rates/html/ index.en.html. Accessed 2 Dec 2018.

Ecocrop FAO (2018) Database. https://ecocrop.fao.org/ ecocrop/srv/en/cropFindForm. Accessed 19 Sep 2018
Giesen W (2013) Paludiculture: sustainable alternatives on degraded peat land in Indonesia. In: Report on activity 3.3 of project, Quick assessment and nationwide screening (QANS) of peat and lowland resources and action planning for the implementation of a National Lowland Strategy. For Partners for Water, the Netherlands (PVW3A10002). Indonesian Ministry of Public Works \& Bappenas, p 71

Giesen W, Nirmala E (2018) Tropical Peatland Restoration Report: the Indonesian case. Tech Rep. https://doi.org/10. 13140/RG.2.2.30049.40808

Graham LLB, Giesen W, Page SE (2016) A Common-sense approach to tropical peat swamp forest restoration in southeast Asia. Restor Ecol 25(2):312-321. https://doi.org/ 10.1111/rec. 12465

Gunarso P, Hartoyo ME, Agus F, Killeen TJ (2013) Oil palm and land use change in Indonesia, Malaysia and Papua New Guinea. In: Reports from the Technical Panels of the 2nd greenhouse gas working Group of the Roundtable on Sustainable Palm Oil (RSPO), pp 29-63. https://www.rspo. org/resources/supplementary-materials. Accessed 24 Apr 2017

Hanley N, Barbier EB (2009) Pricing nature: cost-benefit analysis and environmental policy. Edward Elgar, Cheltenham

Hansson A, Dargusch P (2018) An estimate of the financial cost of peatland restoration in Indonesia. Case Stud Environ. https://doi.org/10.1525/cse.2017.000695

Harrison ME, Rieley JO (2018) Tropical peatland biodiversity and conservation in Southeast Asia Foreword. Mires and Peat 22:1-7. https://doi.org/10.19189/MaP.2018.OMB. 382

Hooijer A, Page S, Jauhiainen J, Lee W, Lu X, Idris A, Anshari $G$ (2012) Subsidence and carbon loss in drained tropical peatlands. Biogeosciences 9(3):1053. https://doi.org/10. 5194/bg-9-1053-2012

Hooijer A, Vernimmen R (2013) Peatland maps for Indonesia. Including accuracy assessment and recommendations for improvement, elevation mapping and evaluation of future flood risk. Quick Assessment and Nationwide Screening (QANS) of Peat and Lowland Resources and Action Planning for the Implementation of a National Lowland Strategy-PVW3A10002. Agentschap NL 6201068 QANS Lowland Development, for Government of Indonesia and Partners for Water (Netherlands)

Huijnen V, Wooster MJ, Kaiser JW, Gaveau DLA, Flemming J, Parrington M, Inness A, Murdiyarso D, Main B, van Weele M (2016) Fire carbon emissions over maritime southeast Asia in 2015 largest since 1997. Sci Rep 6:26886. https:// doi.org/10.1038/srep26886

INDC (2015) Indonesia's intended nationally determined contribution. https://www.unfccc.int/sites/submissions/INDC/ Published\%20Documents/Indonesia/1/INDC_REPUBLIC \%20OF\%20INDONESIA.pdf. Accessed 11 July 2019

Indonesia Government Regulation (2016) Government regulation (Peraturan Pemerintah/PP) No. 57 Year 2016 on amendment to Government Regulation No. 71 of 2014 concerning peatland ecosystem protection and management. https://gambut.oirto.com/en/pp-nomor-57-tahun2016-tentang-perubahan-ppe-gambut/. Accessed 14 Feb 2018 
Jaafar Z, Loh TL (2014) Linking land, air and sea: potential impacts of biomass burning and the resultant haze on marine ecosystems of Southeast Asia. Glob Change Biol 20:2701-2707. https://doi.org/10.1111/gcb.12539

JICA (2017) Data Collection survey on forest \& peatland fire control and peatland restoration in Indonesia (phase 2: final report). https://openjicareport.jica.go.jp/pdf/12300778. pdf. Accessed 17 Mar 2018

Joosten H, Tapio-Biström ML, Tol S (2012) Peatlands: guidance for climate change mitigation through conservation, rehabilitation and sustainable use. FAO. http://www.fao.org/3/ a-an762e.pdf. Accessed 6 Jan 2019

Joosten H, Gaudig G, Tanneberger F, Wichmann S, Wichtmann W (2016) Paludiculture: sustainable productive use of wet and rewetted peatlands. In: Bonn A, Allott T, Evans M, Joosten H, Stoneman R (eds) Peatland restoration and ecosystem services: science, policy and practice ecological reviews. Cambridge University Press, Cambridge, pp 339-357

Law EA, Bryan BA, Meijaard E, Mallawaarachchi T, Struebig M, Wilson KA (2015) Ecosystem services from a degraded peatland of Central Kalimantan: implications for policy, planning, and management. Ecol Appl 25(1):70-87. https://doi.org/10.1890/13-2014.1

Lim KH, Lim SS, Parish F, Suharto R (2012) RSPO manual on best management practices (BMPs) for existing oil palm cultivation on peat. RSPO, Kuala Lumpur

Limin S, Jentha EY (2007) History of the Development of Tropical Peatland in Central Kalimantan, Indonesia. Tropics 16(3):291-301

Maimunah S, Rahman SA, Samsudin YB, Artati Y, Simamora TI, Andini S, Lee SM, Baral H (2018) Assessment of suitability of tree species for bioenergy production on burned and degraded peatlands in Central Kalimantan, Indonesia. Land 7(4):115. https://doi.org/10.3390/ land7040115

Marlier ME, DeFries RS, Kim PS, Koplitz SN, Jacob DJ, Mickley LJ, Myers SS (2015) Fire emissions and regional air quality impacts from fires in oil palm, timber, and logging concessions in Indonesia. Environ Res Lett 10(8):085005. https://doi.org/10.1088/1748-9326/10/8/ 085005

Miettinen J, Shi C, Liew SC (2016) Land cover distribution in the peatlands of Peninsular Malaysia, Sumatra and Borneo in 2015 with changes since 1990. Glob Ecol Conserv 6:67-78. https://doi.org/10.1016/j.gecco.2016.02.004

MoARI (2018) Ministry of Agriculture: agriculture statistic data basis. Kementerian Pertanian Basis Data Statistik Pertanian. Jakarta, Indonesia. https://aplikasi2.pertanian.go.id/ bdsp/id/komoditas. Accessed 14 Feb 2019

MoEFRI (2017) Indonesia Ministerial Regulation of Environment and Forestry No. P.16/MENLHK/SETJEN/KUM.1/ 2/2017 on Technical guidelines for the restoration of peatland ecosystem functions. Jakarta, Indonesia. https:// gambut.oirto.com/permen-no-16-tahun-2017-pedoman-tek nis-pemulihan-fungsi-ekosistem-gambut/. Accessed 14 Feb 2019

MoEFRI (2018) National Peat Ecosystem Function (scale of 1:250,000). Directorate of peat degradation control. Ministry of Environment and Forestry Republic of Indonesia/ Kementerian Lingkungan Hidup dan Kehutanan. Jakarta,
Indonesia. https://gambut.oirto.com/en/fungsi-ekosistemgambut-nasional-skala-1250-000/ Accessed 14 Feb 2019

Moïsé E, Delpeuchi C, Sorescui S, Bottini N, Fochi A (2013) "Estimating the Constraints to agricultural trade of developing countries", OECD Trade Policy Papers, No. 142, OECD Publishing, Paris. https://doi.org/10.1787/ $5 \mathrm{k} 4 \mathrm{c} 9 \mathrm{kwfdx} 8 \mathrm{r}-\mathrm{en}$

MoTRI (2012) Indonesia Ministerial Regulation of Trade No. 44/M-DAG/PER/7/2012 on Goods Subject ot Export Prohibition. Jakarta, Indonesia. https://ditjenpp.kemen kumham.go.id/arsip/bn/2012/bn844-2012.pdf; https:// ditjenpp.kemenkumham.go.id/arsip/bn/2012/bn844-2012la mp.pdf. Accessed 27 Jan 2019

Nion YA, Jemi R, Jagau Y, Anggreini T, Anjalani R, Damanik Z, Torang I, Yuprin Y (2018) Potensi Sayur Organik Lokal Daerah Rawa Di Kalimantan Tengah: "Manfaat Dan Tingkat Kesukaan". Potency of local organic vegetables from swamp region at Central Kalimantan: "benefit and preference". Environ Sci 14(3):259-271. https://doi. org/10.20527/es.v14i3.5698

Nishimura Y (2018) Sago starch: transformation of extraction and consumption processes in traditional Indonesian societies. In: Ehara H, Toyoda Y, Johnson D (eds) Sago PALM. Springer, Singapore

Noor M, Nursyamsi D, Alwi M, Fahmi A (2014) Prospek Pertanian Berkelanjutan di Lahan Gambut: dari Petani ke Peneliti dan Peneliti ke Petani sustainable agriculture. Prospect in peatland: from farmer to researcher and from researcher to farmer. J Sumberdaya Lahan. https://doi.org/ 10.2018/jsdl.v8i2.6469.g5762

Orentlicher M (2019) The potential of sago as a paludiculture crop. MSc thesis Wageningen University, Wageningen, the Netherlands.

Osaki M, Nursyamsi D, Noor M, Wahyunto W, Segah H (2016) Peatland in Indonesia. In: Tropical peatland ecosystems. Springer, Japan, pp 49-58. https://doi.org/10.1007/978-4431-55681-7_3

Page SE, Rieley JO, Banks CJ (2011) Global and regional importance of the tropical peatland carbon pool. Glob Change Biol 17(2):798-818. https://doi.org/10.1111/j. 1365-2486.2010.02279.x

Page SE, Hooijer A (2016) In the line of fire: the peatlands of Southeast Asia. Phil Trans R Soc B 371:20150176. https:// doi.org/10.1098/rstb.2015.0176

PROSEA (2018) Plant resources of South-East Asia database. https://uses.plantnet-project.org/en/Category:PROSEA. Accessed 17 Mar 2018

Ritung S, Wahyunto KN, Sukarman H, Suparto CT (2011) Peta lahan gambut Indonesia. Skala 1:250.000 (Maps of Peatland Distribution in Indonesia). Balai Besar Sumber Daya Lahan Pertanian (BBSDLP) Ministry of Agriculture, Republic of Indonesia

Schoneveld GC, Ekowati D, Andrianto A, van der Haar S (2019) Modeling peat- and forestland conversion by oil palm smallholders in Indonesian Borneo. Environ Res Lett 14(1):014006. https://doi.org/10.1088/1748-9326/ab4870

Sinclair AL, Graham LLB, Putra EI, Saharjo BH, Applegate G, Grover SP, Cochrane MA (2019) Effects of distance from canal and degradation history on peat bulk density in a degraded tropical peatland. Sci Total Environ 699:134199. https://doi.org/10.1016/j.scitotenv.2019.134199 
Sumarga E, Hein L (2015) Benefits and costs of oil palm expansion in Central Kalimantan, Indonesia, under different policy scenarios. Reg Environ Change 16(4):1011-1012. https://doi.org/10.1007/s10113-0150815-0

Sumarga E, Hein L, Edens B, Suwarno A (2015) Mapping monetary values of ecosystem services in support of developing ecosystem accounts. Ecosyst Serv 12:71-83. https://doi.org/10.1016/j.ecoser.2015.02.009

Sumarga E, Hein L, Hooijer A, Vernimmen R (2016) Hydrological and economic effects of oil palm cultivation in Indonesian peatlands. Ecol Soc. https://doi.org/10.5751/ ES-08490-210252

Surahman A, Soni P, Shivakoti GP (2018) Improving strategies for sustainability of short-term agricultural utilization on degraded peatlands in Central Kalimantan. Environ Dev Sustain 21(3):1369-1389. https://doi.org/10.1007/s10668018-0090-6

Surahman A, Shivakoti GP, Soni P (2019) Climate change mitigation through sustainable degraded peatlands management in Central Kalimantan, Indonesia. Int J Commons 13(2):859-866. https://doi.org/10.5334/ijc.893

Tata HL, Susmianto A (2016) Prospek Paludikultur Ekosistem Gambut Indonesia. Forda Press, Bogor

TECA (2015) Technologies and Practices for small agricultural producers: sago plantations on undrained peatland in
Indonesia. FAO. https://www.fao.org/3/ca4045en/ ca4045en.pdf. Accessed 22 May 2017

Uda SK, Hein L, Sumarga E (2017) Towards sustainable management of Indonesian tropical peatlands. Wetl Ecol Manage 25:683-701. https://doi.org/10.1007/s11273-0179544-0

Uda SK, Schouten G, Hein L (2018) The institutional fit of peatland governance in Indonesia. Land Use Policy. https://doi.org/10.1016/j.landusepol.2018.03.031

UNDP Indonesia (2017). Why Indonesia has to save the peatland. The Jakarta Post, 5 January 2017: article by Francine Pickup. https://www.id.undp.org/content/indonesia/en/ home/presscenter/articles/2017/01/09/why-indonesia-hasto-save-the-peatland.html. Accessed 18 Nov 2019

Warren M, Hergoualc'h K, Kauffman JB, Murdiyarso D, Kolka R (2017) An appraisal of Indonesia's immense peat carbon stock using national peatland maps: uncertainties and potential losses from conversion. Carbon Balance Manage 12(1):12. https://doi.org/10.1186/s13021-017-0080-2

Publisher's Note Springer Nature remains neutral with regard to jurisdictional claims in published maps and institutional affiliations. 